\title{
Nucleated Cell Count
}

National Cancer Institute

\section{Source}

National Cancer Institute. Nucleated Cell Count. NCI Thesaurus. Code C150841.

The determination of the amount of nucleated cells present in a sample. 